X線テレビ装置は島津 US-2 型透視台とフイリップス 製シンメトリックス 90/90 透視台, 対象は主に青, 十二 指腸の消化管 $\mathrm{X}$ 線検查, カメラはシネコダック (米) ス ペシアルП型16ミリシネカメラ.

[調査結果並びに考察]

I．X線テレビ装置と従来の透視台を比較してはっき り差のでるのは，医師及び技師の跛労度の差であるす なわちX線テレビ装置では坐ったままの動作ですむ。 た技師の方むカセッテ替えがX線テレビ装犆では，患者 1 人に 1 回ですむのに，従来の透視台で， 5 回出入り するので，X線テレビ装置の 3 倍強を歩いている.

その他X線被曝の完全防止，多数の患者の検查の可能 性など，X線テレビ装置の利点としてあげられる。

II. X線テレビ室のレイアウトについては，人間工学 からみたレイアウトの流れ線図からわかるように, 医師, 技師及び看護婦の動き（流）れを無䭾なくスムースに行 なえるレイアウトであるといえる。

\section{4. イメージインテンシファイアーの輝度測定}

愛知罧がんセンタ一放射線部

○植田俊男・碞 根 戌・田中 義規

イメージインテンシファイアーの出力蛍光面の像を TV 装置で受け, X線透視を行なう場合, 複写体の厚み, 部位によって像の明るさの調整を行なうが，これは TV 系装笽とX線出力の雨者の調整によるここができる. TV 系装置に上る明るさの調整は術者の位置的関係等加 ら比較的不便でありまたその調整の範囲む狭い。 そこで われわれは被写体の厚みが変化しても一定の明るさの得 られるようなX線 ITV に上る透視条件を見い出すとと を目的とした。

[方法]

明るさの測定にはゲルマニウムトランジスター， $2 \mathrm{SD}$ 64, 2SB382 の 2 個によって受光した CdS の電流が 2 段 増幅できる回路を使用した. フィリップス 9 吋イメージ インテンシファイアーの出力蛍光酒の光を上記回路の CdS により受け, 回路に流机る電流值を測定した。透視 条件は管電压 $45 \mathrm{kVp} \sim 90 \mathrm{kVp}, 10 \mathrm{kVp}$ ごとに，管電流 は $0.5 \mathrm{~mA} \sim 3.0 \mathrm{~mA}$ まで変化させた。被写体は水ファン トームを使用しその曆みを $5 \mathrm{~cm}$ から $25 \mathrm{~cm}$ まで $5 \mathrm{~cm}$ で と汇変化させた。

[結果]

一定の明るさまではX線管電圧の増加, 管電流の増加 に伴い，明るさが増すがある値からは増加しない。すな わち明るさが館和するととが判った．被写体の厚みの変 化に対しては管電压を調整した方が効果的であると考え
られる。

\section{X線映画による椎間板造影について}

立川病院放射線科

佐藤喜代治・○須具龍雄 中田 好抒・横山 三吉

[目的]

X線映画の利点は各藏器に打汀る器質的変化をとらえ るととむに，機能的変化を追究し，その動態を把握し運

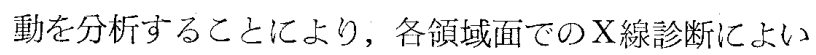
成果をあげていることで岁る. 現在椎間板障害の病熊と して, 椎間板へルニア・椎間板変性・腰椎不安定症等が あるが，乙れらに対し椎間板造影が有力な診断法となっ ている.し加し椎間板変性がもたらす腰椎不安定症など では, 従来の方法によるX線像だけでは椎間板の動的変 化をとらえ難く病態の把握が十分にできぬうらみがある。

われわれは本院整形外科との共同尤り椎間板の動態 を撮影することを目的として，X線咉画による椎間板造 影を行ない臨床成果をあげているので, 撮影法及びその 他について結果を報告する。

〔撮影法】

使用装置として，東芝 KXOの $15 \mathrm{~S}$ 型にフイリップ ス 9 吋の蛍光増倍管をつけ，カメラはボレックスを用い た. 撮影速度は 8 駒及び12駒がよい観察像をとらえてい る. 撮影体位は患者を透視台任側卧位をとらせ造影剂注 入中はそのままの姿勢で撮影する. 次化透視台を立て患 者の骨盤のあたりをべルトで固定し，動摇をふせぎミう 一で観察しながら最大前屈へと体位を変化させ，次江最 大後屈へと徐々に運動させる. との際患者の雨手を保持 し，運動させると動摇むなく容易に撮影が可能である. 〔結論〕

1. 椎間板の動態をとらえ，乙れを再現し観察分析す るのに本法は最適である。

2. 総合晾断と記録保持の面加ら直接撮影す同時に必 要とし，その併用により診断效果をあげ，䧗床成果をあ げられる。

56. Xeroradiography の医学的応用への研究 (第 7 報) 三重大

[目的]

中村 実・山津，啓爾・八谷 䄙紀

われわれはXeroradiography の医学への応用を種々 試みてきたが，今回はXeroradiography に使用する造 影剤について，現在市販されているむのを中心として， その濃度をおの扔のの溶媒で $20 \% ， 5 \% ， 1 \%$ 亿希䐆し たものを使用し，同時に線質も变化させて從来のX線フ 
イルムによる撮影の場合上比較を行ないおのおのの現出 能を検討し臨床応用を試みた。

[実験結果と考案]

1. 希䊅した各市販造影剤の臨床使用可能限度は一部 油性造影剤を除き $20 \mathrm{~g} / 100 \mathrm{~m} l$ までであり，中沉 $10 \mathrm{~g} /$ $100 \mathrm{~m} l \sim 5 \mathrm{~g} / 100 \mathrm{~m} l$ 程度まで使用可能となる.

2. 厚い被写体内にお竹るXero 用造影剤としては目 的部位によっては, 従来の造影滆が適当であるが, 造影 部が含気部と重複するような場合は edge effectにより, その周辺部は像の欠損を生じる.

3. 被写体が薄い場合は, 造影剂の占める容積が大き いほど，また管電圧がある程度高いほど，現出能はよく なるが, edge effectは大となって造影周辺部の像の欠 損を生じやすくなる。

4. 撮影管電圧変化によるXeroの像の現出能は 90 $\mathrm{kVp}$ が最大で, 次いで $130 \mathrm{kVp} \cdot 60 \mathrm{kVp}$ の順である. と の結果は，X線フィルムで行なった結果であるとしろの 低電圧から高電圧になるにしたがい連続的に現出能の低 下するということと異なっている．Xeroの場合，低電 圧よりある程度高電圧になるにしたがい現出能の向上が みられるのは実際撮影時の $\mathrm{mAs}$ 值が少なくてすみ有利 である.

5. 散乱線除去用 Glid の有無の比較においてては，使 用した方が現出能, 画質とむに向上する.ささらに edge effect は Glid の稿目によって，相殺されて少なくなる. 〔総括】

厚い被写体（胸部食道，胃部等）を撮影する場合は Glid 使用々高濃度造影剤使用が効果的である。薄い被写 体（椟頭, 頸部食道）を撮影する場合は，Glid 使用で 比較的薄い造影剤 $20 \mathrm{~g} / 100 \mathrm{~m} l$ でも有效である. 撮影管 電圧は, 被写体の厚さにかかわらずある程度の高圧 (90 $\mathrm{kVp}$ 前後) で少ない $\mathrm{mAs}$ が Xero 汇は適当である.

\section{7. 散乱線線量測定器の比較と較正について}

日本放射線技術学会北海道支部測定委員会 代表発表者 北海道大学付属病院 赤沢 高司

[目的]

近年，放射線機器メーカーでは各種の散乱線測定器を 製作し，われわれも容易にてれらの機器を用いて防護の 状態や散乱線被曝量の推定などに利用しているが，はた しててれらの機器の測定值が認容すべき信頼を有してい るかは不明である，そてで技術学会北海道支部では，北 海道内に保有している散乱線測定器について技術学会で 定められている基準器と相互比較を行ない，すべての機
器がー一致した測定值が得られるように較正率を求奴。 [相互比較の方法】

島津製山城号彰断用装置グレッツ結線(脈動波形), 島 津博愛号深部治療装置グライナッヘル結線(定電王波形) を用い，測定線質は実効電压を $28.6 ， 32.7 ， 48.6 ， 81.5$ $\mathrm{kV}$ の 4 点とし，管電流は測定器の目盛が full scale に なるように任意に定妨。測定距離は約 $5 \mathrm{~m}$ に設定し,

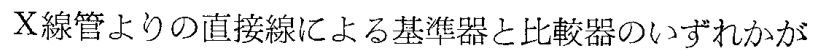
full scale になるようにして，それぞれの指示值の比よ り較正係数を求めた。

〔結果】

相互此較を行なった測定器は19台で，そのメーカーは 4 社のむのがあり，波長依存性については各社とす実効 電圧 $50 \mathrm{kV}$ 付近で最む感度はよく，それを底辺として双 曲線の形をるって上昇している，その感度のバラッキは 各社共に大きく， 0.8 ないし 1.8 と約 2 倍の相違があっ た。

[1年間にお汀る較正係数の変化 $]$

咋年相互比較を行なった 12 台について，1年間にどの 程度の較正係数に変化があったがついて調查すると， 変化なしが 5 台，僅が変化あり 5 台，変化ありが 2 台 でそのうち 1 台は原因不明で 1 台は故障修理を行なって いた.

〔測定器の許容電源について

電池式の測定器で使用が認められる電圧内で，はたし て測定值に変化がないかをたしかめるために電池に可変 抵抗を接続して, 測定值の変化を調べてみると, 測定器 の許容最低電圧付近では感度低下が認妨えれす。 した がって電池式測定器では現在よりむさらに許容電圧範囲 をせばめる必要があると思います。

\section{Soft.X-Ray 領域における 線量測定の諸問題と物} 理的考案

立正佼成会付属 佼成病院放射線科

渡辺 和夫・原尾 基継

染谷 清二・速水 昭雄

[緒言]

軟X線の開発による長波長 $\mathrm{X}$ 線の利用は，医療面にお いては，皮䖉䛈患の治療及び軟部組織の撮影に応用され るようになった。 との場合, 特に問題となるのは, 線量, 線質の変化を的確汇把握して置くことは非常に重要なと とである. そこでしの Soft-X-Ray 領域における問題に 対して種々の実験を施行し，興味ある結果を得たのでし とにその一部を報告する。

[その 1 電流汇よる線量特性] 